\title{
SERUM 5-NUCLEOTIDASE
}

BY

\author{
THEODORE F. DIXON AND MARY PURDOM
}

From the Biochemistry Department, the Institute of Orthopaedics, Stanmore, Middlesex

(RECEIVED FOR PUBLICATION DECEMBER 8, 1953)

Reis $(1934,1940,1951)$ has demonstrated the presence of alkaline phosphatase in various tissues specifically hydrolysing 5-nucleotidase such as adenosine and inosine-5-phosphoric acids. The enzyme has its optimum action at $p \mathrm{H} 7.8$ and in all human tissues except intestinal mucosa its activity, at the physiological $p \mathrm{H}$ range, is much more pronounced than that of the non-specific alkaline phosphatase. Thus ossifying cartilage, one of the classical sites of high alkaline phosphatase activity, although very active against say phenyl phosphoric acids at $p \mathrm{H} 9$, is more active against adenosine-5phosphoric at $p \mathrm{H}$ 7.5. This finding suggested to Reis that the enzyme might play a part in calcification mechanisms. Studies designed to elucidate the physiological significance of phosphatase are frequently based on measurements of enzyme activity in blood serum or plasma, and there is an enormous literature dealing with such variations caused by different pathological conditions. It seemed, therefore, of interest to determine the activity of both serum-5-nucleotidase and non-specific alkaline phosphatase in a number of disease states.

\section{Reagents}

Glycerophosphate Buffer Substrate pH 9.3.-Sodium $\beta$.glycerophosphate, $0.05 \mathrm{~g}$., sodium barbitone $0.424 \mathrm{~g}$. made up to $100 \mathrm{ml}$. with water, adjusted to $p \mathrm{H} 9.3$ and stored in the cold.

Glycerophosphate Buffer Substrate pH 7.5.-As above except that the $p \mathrm{H}$ is adjusted to 7.5 by adding approx:mately $1.2 \mathrm{ml}$. $\mathrm{N} \mathrm{HCl}$.

Adenosine-5-phosphate Buffer Substrate pH 7.5.Adenosine-5-phosphate, $0.087 \mathrm{~g}$., and sodium barbitone, $0.424 \mathrm{~g}$., made up to $100 \mathrm{ml}$. with water and the $p \mathrm{H}$ adjusted to 7.5 by adding $1.2 \mathrm{ml}$. N HCl and stored in the cold.

Aminonaphtholsulphonic Acid Reagent.-Fifteen per cent. sodium bisulphite, $195 \mathrm{ml}$., 1,2,4-aminonaphtholsulphonic acid, 0.5 g., $20 \%$ sodium sulphite, $5 \mathrm{ml}$., stoppered and shaken until dissolved and stored in the cold and used within four weeks.

Molybdate Reagent.-Reagent grade ammonium molybdate, $25 \mathrm{~g}$., dissolved in about $200 \mathrm{ml}$. water. In a 1-litre volumetric flask place $300 \mathrm{ml} .10 \mathrm{~N} \mathrm{H}_{2} \mathrm{SO}_{4}$, add the molybdate solution, and dilute with washings to 1 litre with water.

Standard Phosphate Solution.- $-\mathrm{KH}_{2} \mathrm{PO}_{4} 0.02195$ g., and $50 \mathrm{~g}$. trichloracetic acid, made up to 1 litre. This solution contains $0.02 \mathrm{mg}$. $P$ in $4 \mathrm{ml}$.

\section{Methods}

Non-specific alkaline phosphatase activity is high at $p \mathrm{H} 9$ towards phenylphosphate adenosine phosphate and glycerophosphate, in this decreasing order (cf. Reis, 1951). At $p \mathrm{H} \mathrm{7.5,} \mathrm{however,} \mathrm{the} \mathrm{total} \mathrm{phosphatase}$ activity is equally low towards phenyl- or glycero-phosphate and the higher activity towards adenosine-5phosphate at this reaction is reasonably inferred to be due to the specific 5-nucleotidase. Serum 5-nucleotidase activities were thus measured by subtracting the nonspecific phosphatase activity with glycerophosphate as substrate at $p \mathrm{H} 7.5$ from the total activity with adenosine-5-phosphate at 7.5. Serum non-specific phosphatase activities were determined by incubation with glycerophosphate at $p \mathrm{H}$ 9.3. Thus for the test solutions $0.2 \mathrm{ml}$. serum was mixed with $4.5 \mathrm{ml}$. of the appropriate eombined buffer substrate mixture and $0.3 \mathrm{ml}$. of water and incubated at $37^{\circ} \mathrm{C}$. for two and a half hours. Then the tubes were removed from the incubator and immediately mixed with $1 \mathrm{ml}$. of $30 \%$ trichloracetic acid, allowed to stand for a few minutes, and filtered. In another tube a control is prepared in an exactly similar manner without incubation. To $4 \mathrm{ml}$. each of the trichloracetic filtrates and standard phosphate solution are added $0.5 \mathrm{ml}$. of molybdate reagent, $0.2 \mathrm{ml}$. aminonaphtholsulphonic acid reagent, and $0.3 \mathrm{ml}$. of water. After 15 minutes the colours are read in the spectrophotometer at $660 \mathrm{~m} \mu$.

\section{Calculation}

Adenosine-5-phosphate buffer substrate $p \mathrm{H} 7.5=\mathrm{A}$

Glycerophosphate buffer substrate $p \mathrm{H} 9.3=\mathrm{G} 9.3$

Glycerophosphate buffer substrate $p \mathrm{H} 7.5=\mathrm{G} 7.5$

Alkaline phosphatase (units $/ 100 \mathrm{ml}$.) $=$

$$
\frac{\text { Reading of G } 9.3 \text { (test }- \text { control) }}{\text { Reading of standard }} \times 6
$$

5-nucleotidase (" units " $/ 100 \mathrm{ml}$.) =

Reading of A (test - control)-

$\frac{\text { Reading of G } 7.5 \text { (test }- \text { control) }}{\text { Reading of standard }} \times 6$ 
The alkaline phosphatase activities are thus in Bodansky units and the method is essentially that of Shinoware, Jones, and Reinhart (1942). This method of expression, rather than the King-Armstrong phenol unit, was chosen to allow a ready comparison with the 5-nucleotidase activities.

\section{Results}

When determinations of the two enzyme activities were made on a number of different sera it became apparent that results fell into three main groups (Table I).

TABLE I

SERUM ADENOSINE-5-PHOSPHATASE AT $p H \quad 7.4$ COMPARED WITH NON-SPECIFIC GLYCEROPHOSPHATASE AT pH 9.3 ("BODANSKY UNITS")

\begin{tabular}{|c|c|c|c|}
\hline Group & $\begin{array}{l}\text { Adenosine-5- } \\
\text { phosphatase } \\
\text { at } p \mathrm{H} 7.4\end{array}$ & $\begin{array}{c}\text { Alkaline } \\
\text { Phosphatase } \\
\text { at } p \mathrm{H} 9.3\end{array}$ & $\begin{array}{c}\text { Disease State } \\
\text { (No. of Cases Examined } \\
\text { in Brackets) }\end{array}$ \\
\hline I & $\begin{array}{l}\text { Normal } \\
0-1.6 \text { units }\end{array}$ & $\begin{array}{l}\text { Normal } \\
2-5 \text { units }\end{array}$ & $\begin{array}{l}\text { Rheumatoid arthritis (17). } \\
\text { Tuberculous spine (12). Pul- } \\
\text { monary tuberculosis (1), } \\
\text { Osteoporosis (1). Myeloma } \\
\text { (2). Osteogenic sarcoma. } \\
\text { hip (1). Swollen ankles (1). } \\
\text { Gouty toes (1). Kyphosis (2). } \\
\text { Muscle injury (1). Osteitis, } \\
\text { Osteoarthritis, litioconden- } \\
\text { sans (1). Fragilitas ossium } \\
\text { (1). Nephrocalcinosis (1) } \\
\text { Suspected jaundice (13). } \\
\text { Xanthomatosis (1). ? Myx- } \\
\text { oedema (1). Prolapsed disc } \\
\text { (1) }\end{array}$ \\
\hline II & $\begin{array}{l}\text { Normal } \\
0-1.6 \text { units }\end{array}$ & $\begin{array}{l}\text { Raised } \\
9-19.3 \text { units }\end{array}$ & $\begin{array}{l}\text { Paget's disease (3). Rickets (6). } \\
\text { Albright's syndrome (1) } \\
\text { Breast cancer (2). Spinal } \\
\text { neoplasm (1) }\end{array}$ \\
\hline III & $\begin{array}{c}\text { Raised } \\
1.7-36 \text { units }\end{array}$ & $\begin{array}{l}\text { Raised } \\
4 \cdot 1-22 \text { units }\end{array}$ & $\begin{array}{l}\text { Tuberculosis with amyloid (4). } \\
\text { Jaundice (22). Polycystic } \\
\text { kidney with uraemia (1) }\end{array}$ \\
\hline
\end{tabular}

First Group.-Both 5-nucleotidase and nonspecific alkaline phosphatase values were low in normal men, and a number of miscellaneous conditions.

Second Group.-5-Nucleotidase was low and nonspecific alkaline phosphatase values were high in rickets, Paget's disease, osteogenic tumours, Albright's syndrome, breast cancer, and spinal neoplasm.

Third Group.-Both 5-nucleotidase and nonspecific alkaline phosphatase values were high in obstructive and infective jaundice, liver haemangioma, lung or bone tuberculosis with amyloid, and polycystic kidney.

Results of other criteria for liver function have not shown precise correlation with the high nucleotidase values in the third group as can be seen in Table II. Sera with low bilirubin contents may have high nucleotidase activities and raised nucleotidase does not exactly parallel raised serum alkaline
TABLE II

DETAILS OF CASES IN GROUP III

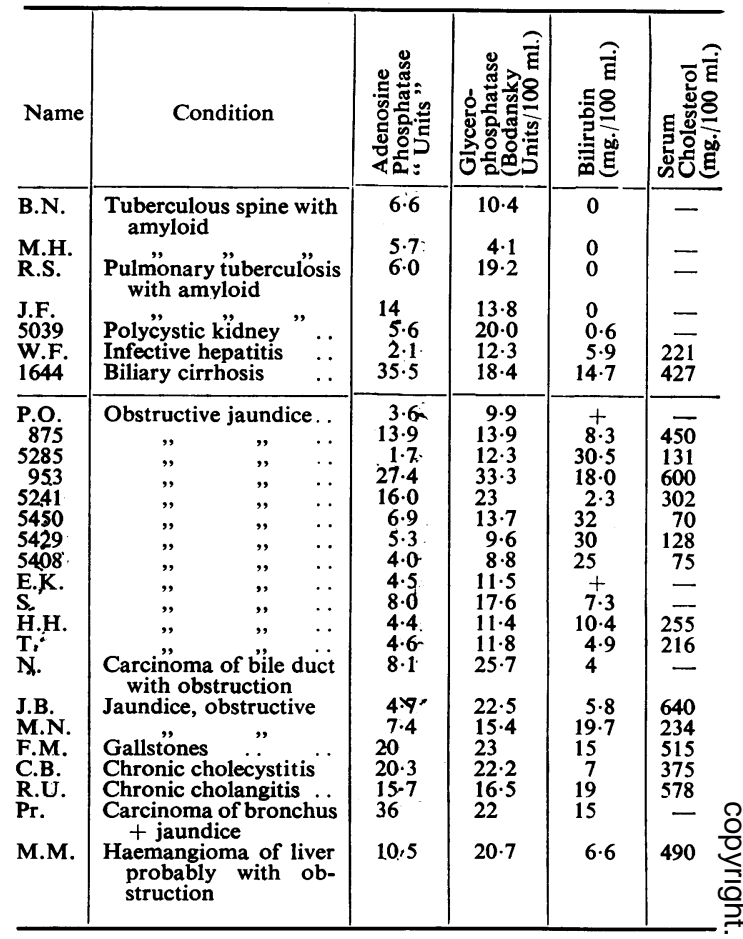

phosphatase. Thus one case (M. H.) showed a low 5-nucleotidase (1.5) value during the peak of his "jaundice" (bilirubin $17 \mathrm{mg} . / 100 \mathrm{ml}$. and 9.9 units alkaline phosphatase) but two months later a higher 5-nucleotidase (5.7) value with lowered alkaline phosphatase (4.1) and no bilirubinaemia. In general, however, it can be said that serum cholesterol, alkaline phosphatase, and 5-nucleotidase are increased together but not to the same extent.

The serum activity curves at varying $p \mathrm{H}$ values from a particular case of jaundice having high 5-nucleotidase activity are shown in Fig. 1 with adenosine-5-phosphate and $\beta$-glycerophosphate as substrates. This gives further proof of the occurrence of high concentrations of this specific 5nucleotidase with an optimum at about $p \mathrm{H} 7.5$ in some sera.

Attempts to induce liver damage in two rabbits by twice weekly carbon tetrachloride $(1 \mathrm{ml} . / \mathrm{kg}$.) injections for six weeks, although raising the serum cholesterol from 23 to $297 \mathrm{mg}$./100 ml., did not alter the 5-nucleotidase from 0.2 units although the alkaline phosphatase increased slightly from 0.5 and 0.9 units to 0.85 and 1.9 units per $100 \mathrm{ml}$. respectively.

Similarly in attempts to produce liver disease in rats, $5 \%$ by weight of bromobenzene was added to 
FIG. 1.-Hydrolysis of adenosine-5-phosphate and of $\beta$-glycerophosphate by blood serum of jaundiced patient (Pr.) at varying $p \mathrm{H}$ values. $\mathbf{A}=$ adenosine-5-phosphate; $\mathbf{B}=\beta$-glycerophosphate.

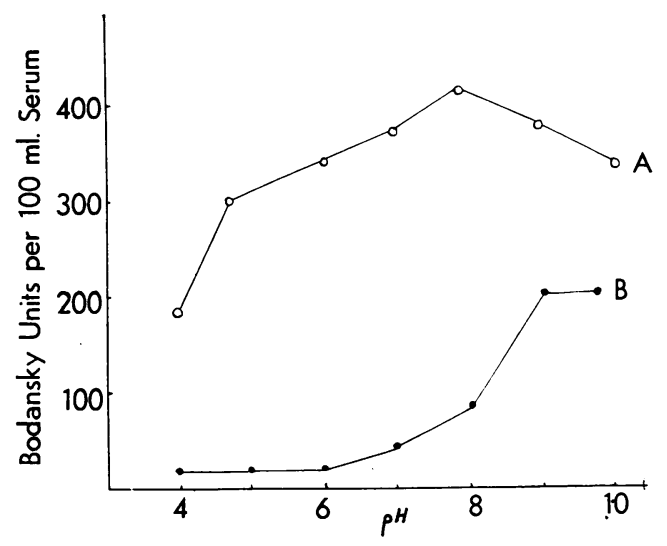

the stock diet of $150 \mathrm{~g}$. rats for 6 weeks as described by Koch-Weser, de la Huerga, Yesinick, and Popper (1953). The serum 5-nucleotidase and alkaline phosphatase of these rats, respectively 2.1 and 14.3, was not appreciably different from the 2.1 and 14.6 of the control group.

\section{Discussion}

Although intestine and liver are regarded as contributors to the normal serum alkaline phos- phatase level there seems general agreement that bone also is the source of at least some of it, and that the hyperactive osteoid tissue in, for example, rickets, produces the high level in that condition. Serum alkaline phosphatase is elevated only in cases where formation of some kind of osseous tissue is proceeding. In hyperparathyroidism, Paget's disease, and rickets, serum alkaline phosphatase values run roughly parallel with the severity. Normal values are found in osteoporosis and in bone tumours unless they are osteoplastic.

The results described above show that a high serum alkaline phosphatase level from liver disease is usually accompanied by a 5-nucleotidase value increased as much as a hundredfold whereas that from bone disease is not. Bone, therefore, is not likely to be the source of serum 5-nucleotidase.

The authors wish to express grateful thanks to Professors C. H. Gray, E. J. King, and N. F. MacLagan and Dr. D. N. Baron and Miss E. W. M. Johnson for making available some of the sera and information concerning them.

\section{REFERENCES}

Koch-Weser, D., Huerga, J. de Ia, Yesinick, C., and Popper, H (1953). Metabolism, 2, 248.

Reis, J. (1934). Bull. Soc. Chim. biol. Paris, 16, 385. (1940). Ibid., 22, 36.

- (1951). Biochem. J., 48, 548.

Shinowara, G. Y., Jones, L. M., and Reinhart, H. L. (1942). J. biol. Chem., 142, 921. 